\title{
An Assessment of the Copyright Model in Right of Publicity Cases
}

In popular culture, both a performer's act and his or her name and likeness have commercial value. The right of the performer or publicity figure ${ }^{1}$ to control these assets, most appropriately called the right of publicity, is itself the work of creative endeavors by courts and commentators who have attempted to define the scope of the right-its duration, its conditions of applicability, and its benefactors. These attempts have led to the adoption of analogies based on other bodies of law..$^{2^{-}}$Nowhere is the use of analogy more evident than in the course of the Lugosi v. Universal Pictures ${ }^{3}$ litigation, which generated four opinions as to the ownership of the commercial rights to the image of Bela Lugosi's portrayal of Count Dracula. The four opinions characterized the right of publicity as a property right, ${ }^{4}$ a privacy right, ${ }^{5}$ an employerowned product of einployment, ${ }^{6}$ and a proprietary right which should be treated like a copyright. ${ }^{7}$

1. The term "publicity figure" describes persons who, by virtue of public exposure, generate an interest in their lives and likenesses. This group includes celebrities, public figures, entertainers, and athletes.

2. Felcher \& Rubin, The Descendibility of the Right of Publicity: Is There Commercial Life After Death?, 89 YALE L.J. 1125, 1127-32 (1980). The Second Circuit was the first court to recognize a right of publicity distinct from a right of privacy. See Haelan Laboratories, Inc. v. Topps Chewing Gum, Inc., 202 F.2d 866 (2d Cir.), cert. denied, 346 U.S. 816 (1953) (applying New York law). Then Circuit Judge Frank expressly disclaimed rehance on any common law model, writing that '[w] hether [the right of publicity] be labelled a 'property' right is immaterial; for here, as often elsewhere, the tag 'property' simply symbolizes the fact that courts enforce a claim which has pecuniary worth." $I d$. at 868. Since Haelan, courts have used common law labels or models as guides to determine the characteristics of the right of publicity. E.g., Cepeda v. Swift \& Co., 415 F.2d 1205, 1206-07 (8th Cir. 1969) (plaintiff had "property right"; sole issue was whether plaintiff's contract authorized "use of plaintiff's naine and photograph in the manner in which they were used"); Uhlaender v. Henricksen, 316 F. Supp. 1277, 1282-83 (D. Minn. 1970) (using a property formulation); Lugosi v. Universal Pictures, 25 Cal. 3d 813, 821-24, 603 P.2d 425, 430-31, 160 Cal. Rptr. 323, 328-29 (1979) (holding that the tenets of privacy law are controlling); Id. at 844-49, 602 P.2d at 444-47, 160 Cal. Rptr. at 342-45 (Bird, C.J., dissenting) (using analogy to federal copyright law). Commentators have done inuch the same. E.g., Gordon, Right of Property in Name, Likeness, Personality, and History, 55 Nw. U.L. Rev. 553 (1960); Comment, The Right of PublicityProtection for Public Figures and Celebrities, 42 BROOKLYN L. REv. 527 (1976) (positing that the right of publicity is a property right); Comment, Transfer of the Right of Publicity: Dracula's Progeny and Privacy's Stepchild, 22 U.C.L.A. L. REv. 1103, 1124-28 (1975) (suggesting that an analogy be drawn between copyright and the right of publicity).

3. 25 Cal. 3d 813, 603 P.2d 425, 160 Cal. Rptr. 323 (1979).

4. Lugosi v. Universal Pictures Co., 172 U.S.P.Q. (BNA) $541,548-49$ (Cal. Super. Ct. 1972).

5. 25 Cal. 3d at 819-24, 603 P.2d at 428-31, 160 Cal. Rptr. at 326-29.

6. Id. at 824-28, 603 P.2d at 431-34, 160 Cal. Rptr. at 329-32 (Mosk, J., concurring).

7. Id. at $844-49,603$ P.2d at 444-47, 160 Cal. Rptr. at $342-45$ (Bird, C.J., dissenting). 
This Comment concludes that personal and societal interests in right of publicity cases are best advanced under a common law scheine that parallels copyright law. Copyright itself embraces two models: a traditional copyriglit model based on the policies of encouraging creative effort and protectimg the fruits of one's labor, and an alternative byproduct model based principally on the traditional model's secondary goal of protecting the creator agamst the unjust enrichment of those seeking to exploit the merchantable creation. These two models match up with the two types of right of publicity cases-publicity rights to performance and publicity rights to the perforner's image, a valuable byproduct of creative or athletic efforts. This Comment argues that performance cases should be guided by the traditional model and image cases should be determined by applying the byproduct model.

Part I of this Comment examines the proposed inodes of treatment articulated in Lugosi. Part II considers an alternative copyright model based on commercial fairness that protects the images of graphic characters. Part II concludes that this model should be apphed to those publicity cases mvolving appropriation of a celebrity's likeness. Part III applies the byproduct model and concludes that the right of publicity is descendible, that post mortem exploitation should not depend on lifetime exploitation, and that the right inures to an actor in his portrayal of a fictional character.

\section{I \\ The Proposed Models of ANalysis}

\section{A. The Lugosi Scenario}

Bela Lugosi portrayed Count Dracula in Universal Pictures' 1931 motion picture "Dracula." Though other notable actors have donned the black cape of the vampire, it was Lugosi's Dracula that created the most vivid and lastimg impression. ${ }^{8}$ A resurgence of popularity im vin-

8. One pop culture critic writes:

Lugosi, with his sticked-back black hair, piercing eyes, predatory profile, and rich Hungarian accent, became permanently identified with the role, even though he played it only twice in films (and on one of those occasions, at that, in a comedy). He looked almost nothing like the white-haired, nustachioed old nan described by Bram Stoker, but Lugosi's highly theatrical performance was so effective that his face has become Dracula's face and his voice, Dracnla's voice.

L. Daniels, Living in Fear: A History of Horror in the Mass Media 130 (1975). See also I. BUTLER, HORROR IN THE CINEMA 42 (2d ed. 1970) (Lugosi "invested the character with a formidable dignity and stalked about the West End in his cloak and top-hat with ghastly relish").

Universal's conduct suggests that it beheved Lugosi to be the quintessential vampire. Universal obtained Lugosi's written permission to use his likeness for a wax bust in the 1936 film "Dracula's Daughter." Twelve years later, it asked Lugosi to make a cameo appearance as Count Dracula in "Abbott and Costello Meet Frankenstein." Lugosi v. Universal Pictures Co., 172 U.S.P.Q. (BNA) 541, 541-42 (Cal. Super. Ct. 1972). 
tage horror films and their characters began in 1960, four years after Lugosi's death.9 This was evinced not only in movie houses and on late-night television, but also in pop culture merchandise like T-shirts, posters, and models.

Universal entered into licensing agreements with commercial merchandisers authorizing the use of the Count Dracula image. Bela Lugosi's distinct Dracula image ultimately appeared on T-shirts, plastic models, masks, playing cards, picture puzzles, belt buckles, and bar accessories. The Lugosi lawsuit was brought to determine the post morten rights of control over the actor's name and likeness. Bela George Lugosi and Hope Linninger Lugosi, the actor's surviving son and widow, sought mjunctive relief and recovery of Universal's profits on the ground that the studio engaged in allegedly unauthorized exploitation of a valuable property right belonging to the deceased actor's estate. $^{10}$

\section{B. The Proposed Modes of Treatment}

The Lugosi litigation generated four opinions seeking to define the "right of value" "11 to one's name and likeness. The opinions articulate a property model, a privacy model, a work product model, and a copyright inodel. While the first three models have their strengths, each fails to account adequately for the personal and societal interests in right of publicity cases. The copyright model best accounts for the nexus of interests. This Comment argues that the copyright model can be broken down into two related frameworks for analysis and proposes that the byproduct copyright model should be followed in image-marketing cases because of its precise weighting and balancing of the relevant societal imterests.

\section{The Trial Court Opinion: The Property Model}

The Lugosi trial court adopted a property model which recognizes that the rights to one's commercially valuable name and likeness are possessory rights accruing as the fruits of one's labor. ${ }^{12}$ The property analogy grants control over this asset to its creator. Thus, the publicity figure's interest is more than the right to profit from his image; it addi-

9. See Lugosi v. Universal Pictures Co., 172 U.S.P.Q. (BNA) 541, 542 (Cal. Super. Ct. 1972).

10. The trial court had earlier determined that Lugosi's estate was the proper plaintif. After Lugosi's widow and son were subsequently awarded all causes of action belonging to the estate, the litigation culminating in the California Supreme Court decision recommenced.

11. This term, used by the Lugosi majority, $25 \mathrm{Cal} .3 \mathrm{~d}$ at 819, 603 P.2d at $428,160 \mathrm{Cal}$. Rptr. at 326, originates with Prosser. See W. PROSSER, LAW OF TORTs $§ 117$, at 807 (4th ed. 1971).

12. See Uhlaender v. Henricksen, 316 F. Supp. 1277, 1282 (D. Minn. 1970). 
tionally includes the right to manage his image as he sees fit. ${ }^{13}$

Two conclusions follow from the property characterization. First, the right, like other property rights, is assignable. This corollary was reached in Haelan Laboratories, Inc. v. Topps Chewing Gum, Inc. ${ }^{14}$ Haelan Laboratories was the first case to recognize a right of publicity distmct from a nonassignable right of privacy. ${ }^{15}$ The court noted that for the publicity figure to exploit his name or likeness to tlie maximum extent possible lie must be able to hicense and assign it to others. ${ }^{16}$ The second conclusion following from the property characterization is that the right of publicity, like personal property, is descendible. This conclusion was the holding of the Lugosi trial court. ${ }^{17}$

Granting a possessory right to one's image accounts for the creator's personal interests in marketing control. In addition, the property model implicity advances the societal interests in encouraging artistic endeavor ${ }^{18}$ and guarding against the appropriation of what inay be characterized as the goodwill generated by the performer's marketable name and likeness. The weakness of the property model, however, lies in its failure to recognize countervailing social interests in free enterprise and free expression.

The interests in free enterprise were articulted by the Sixth Circuit in Memphis Development Foundation v. Factors, Etc., Inc. ${ }^{19}$ The court reasoned that " $[t]$ he inemory, naine and pictures of famous mdividuals should be regarded as a common asset to be shared, an economic opportumity available in the free market systein." 20 The court held that this interest in a free nnarket outweighed "the added motivation and extra creativity supposedly encouraged by allowing a person to pass on

13. The pop figure is not satisfied simply with remuneration for the use of his or her name or likeness because such rewards do not protect against the wasting of this asset by competing entrepreneurs or by those who have only a short-term interest in promoting a given product rather than a long-term imterest in maintaining the image's commercial value. Public backlasl in response to market saturation is a recurring phenomenon in the entertaininent world. Unless the public figure has marketing control by license or assignment over the commercial use of his name or likeness, the asset's value is reduced because it is subject to waste by self-interested entrepreneurs.

14. 202 F.2d 866 (2d Cir.), cert. denied, 346 U.S. 816 (1953).

15. See generally Prosser, Privacy, 48 CALIF. L. Rev. 383 (1960).

16. 202 F.2d at 868. See also Gordon, supra note 2, at 601.

17. 172 U.S.P.Q. (BNA) 541, 551 (Cal. Super. Ct. 1972). See also Price v. Hal Roach Studios, Inc., 400 F. Supp. 836, 844 (S.D.N.Y. 1975) (contrasting commercial imterests, which last beyond actor's death, with personal privacy interest terminating at death).

18. To the extent that recognition of a possessory right to one's image provides increased financial opportunity for those who choose to engage in the performing arts or athletics, it encourages endeavor in these fields. Chief Justice Bird stated in the Lugosi dissent that a right of publicity "creates a powerful imcentive for expending time and resources to develop the skills or achievements prerequisite to public recognition." $25 \mathrm{Cal} .3 \mathrm{~d}$ at $840,603 \mathrm{P.2d}$ at $442,160 \mathrm{Cal}$. Rptr. at 340 (Bird, C.J., dissenting). But see infra notes 57-64 and accompanying text.

19. 616 F.2d 956 (6th Cir.), cert. denied, 449 U.S. 953 (1980).

20. Id. at 960 . 
his fame for commercial use of his heirs or assigns."21

Interests in free expression are also implicated because pop and public figures are pillars of popular culture. Their names and images represent the wide variety of American cultural values, ranging from the triumphant ${ }^{22}$ to the comically beleaguered, ${ }^{23}$ from the spiritual ${ }^{24}$ to the irreverent. ${ }^{25}$ Granting full monopoly power to such figures and their heirs may chill or quell the exchange of socially desirable information concerning the hives and exploits of pop culture heroes and heroines. ${ }^{26}$ Thus, any recognition of a right of publicity must be tailored so as not to run afoul of the first amendment's guarantees of free speech and exchange of ideas. The property model's shortcoming is its failure to balance the free speech and free enterprise interests against the personal and societal interests that it effectively promotes.

\section{The Majority Opinion: The Privacy Model}

The state court of appeal rejected the Lugosi trial court's holding that the right is a property right, instead identifying it as a nondescendible privacy interest. The Lugosi majority ultimately adopted the court of appeals opimion. ${ }^{27}$ The interest protected in a privacy action is the plaintiff's mental well-being-in short, the right to be left alone. ${ }^{28}$ The

21. Id.

22. See Ali v. Playgirl, Inc., 447 F. Supp. 723, 726-27 (S.D.N.Y. 1978) (featuring the likeness of Muhammad Ali).

23. See Price v. Hal Roael Studios, Inc., 400 F. Supp. 836, 837 (S.D.N.Y. 1975) (involving commercial portrayals of Laurel and Hardy).

24. The name and likeness of jazz inusician John Coltrane became the syunbol of San Francisco's One-Mind Teinple Evolutionary Transitional Churcl of Christ, whose caunpaign, if religious, was also commercial. The church used Coltrane's visage and lyrics from his 1964 "Love Supreine" album to help sell T-shirts, incense, and bread. Nat'l L.J., Nov. 9, 1981, at 39, col. 1.

25. Groucho Marx Prods., Inc. v. Day \& Night Co., 523 F. Supp. 485, 486 (S.D.N.Y. 1981) (concerning the use of the names, likenesses, and mannerisms of the antiheroic Marx Brothers in a Broadway show).

26. In a concurring opinion to Guglielmi v. Spelling-Goldberg Prods., 25 Cal. 3d 860, 603 P.2d 454, 160 Cal. Rptr. 352 (1979), a compamion case to Lugosi, Chief Justice Bird, jomed by Justices Tobriner and Manuel, articulated the public interests in limiting the right of publicity. Slue wrote:

Conteinporary events, syunbols and people are regularly used in fictional works. Fiction writers inay be able to inore persuasively, more accurately express themselves by weaving into the tale persons or events familiar to their readers. The choice is theirs. No author should be forced into creating inythological worlds or characters wholly divorced from reality. The right of publicity derived froun public prominence does not confer a shield to ward off caricature, parody and satire. Rather, prominence invites creative comment. Surely, the range of free expression would be meaningfully reduced if prominent persons in the present and recent past were forbidden topics for the imagimations of authors of fiction.

Id. at 869, 603 P.2d at 460, 160 Cal. Rptr. at 358 (Bird, C.J., concurring) (footnotes omitted).

27. The California Supreme Court's opinion contamed minor revisions, which were noted, but did not alter the substance of the court of appeals opinion.

28. Prosser, supra note 15, at 389. 
privacy characterization stems from Dean Prosser's dissection of the right of privacy into four distinct tort actions, ${ }^{29}$ including the appropriation of plaintiff's name or likeness for defendant's commercial benefit. $^{30}$ The classic scenario illustrating this branch of the tort is the use of the face of a private individual in advertising defendant's products. ${ }^{31}$ To find that one's image, for exainple, graces advertisements for flour is understandably discomforting.

The privacy model has been roundly criticized by both courts and commentators. ${ }^{32}$ As noted first in Haelan Laboratories, the right of publicity is distinct from the right of privacy ${ }^{33}$; the publicity right protects a financial interest, the privacy right an emotional or dignitary interest. As a result, the privacy inodel is inapphicable to cases involving celebrities and public figures who voluntarily expose theinselves and their exploits to public view. To such persons, public exposure is desirable and thus does not invade any dignitary interest protected by the right of privacy.

However woeful the celebrity's prospects of sustaining a privacy action during life, it is clear that such an action cannot be sustained after death. ${ }^{34}$ Third parties, including family, have no legal interest in the deceased's reputation. Therefore, under the privacy inodel the theoretically protectible but practically unsustainable right to commercial exploitation in life devolves to the public upon the celebrity's death. Thus, once the Lugosi inajority characterized the right as a privacy right, it followed that this right terminated upon the actor's death.

\section{The Mosk Concurrence: The Work Product Model}

Justice Mosk concurred in the Lugosi result but not with the inajority's rationale. He believed that no proprietary rights inured to Lu-

29. Id. at 383-401. Prosser characterized the first three invasions of privacy as: (1) an intrusion upon the plaintiff's seclusion or solitude or into his private affairs, (2) public disclosure of private facts, and (3) the placing of the plaintiff in a false light before the public eye.

30. Id. at 401-07.

31. Pavesich v. New England Life Ins. Co., 122 Ga. 190, 50 S.E. 68 (1905). $C f$. Roberson v. Rochester Folding Box Co., 171 N.Y. 538, 64 N.E. 442 (1902) (refusing to recognize a privacy right inuring to a young woman whose likeness was used without her consent and much to her humiliation in a flour advertising campaign).

32. E.g., Haelan Laboratories, Inc. v. Topps Chewing Gum, Inc., 202 F.2d 866, 868 (2d Cir.), cert. denied, 346 U.S. 816 (1953); Uhlaender v. Henricksen, 316 F. Supp. 1277, 1279-81 (D. Minn. 1970); Felcher \& Rubin, supra note 2, at 1128; Gordon, supra note 2, at 555-57; Note, Dracula Draws Blood from the Right of Publicity, 15 SuFFoLK U.L. REv. 181 (1981).

33. 202 F.2d at 868.

34. See Maritote v. Desilu Prods., Inc., 345 F.2d 418 (7th Cir.), cert. denied, 382 U.S. 883 (1965); Jaines v. Screeu Gems, Inc., 174 Cal. App. 2d 650, 344 P.2d 799 (2d Dist. 1959). Cf. RESTATEMENT (SECOND) OF TORTS $\S 6521$ (1977) (an action for invasion of privacy can be inaintained only by a living individual whose privacy has been invaded, except for actions involving the appropriation of one's name and likeness). 
gosi because (1) it was the image of Count Dracula and not Bela Lugosi that was inarketed, and (2) an einployee's creation in the course of his employment belongs to the einployer pursuant to section 2860 of the California Labor Code. ${ }^{35}$ Thus, unlike the majority, which concluded that upon Lugosi's death the image of Dracula as portrayed by Lugosi fell into the public donnain, Justice Mosk believed that control over the image always belonged exclusively to the studio.

Justice Mosk thus raised the issue of who has rights to the likeness of a dramatic character. He conceded that an actor's likeness as a fictional character may be protectible when that actor is also the character's creator, contemplating rights belonging to Grouclio Marx, ${ }^{36}$ Stan Laurel, and Oliver Hardy. ${ }^{37}$ Justice Mosk found, however, that "[in]erely playing a role . . . creates no inheritable property riglt in an actor . . .."38 In suin, creation of a marketable character leads to an inheritable property interest but performance as a inarketable character does not. ${ }^{39}$ Whether the Dracula image is a studio creation-as posited by Justice Mosk-is an important question. This Comment suggests that the combination of the actor's and studio's creative efforts should not defeat the commercial interests of either or both parties.

35. Lugosi v. Universal Pictures, 25 Cal. 3d at 824-28, 603 P.2d at 431-34, 160 Cal. Rptr. at 329-32 (Mosk, J., concurring). CAI. LAB. CODE $\S 2860$ (West 1971) reads: "Everything which an employee acquires by virtue of his employment, except the compensation which is due to him from his employer, belongs to the employer, whether acquired lawfully or unlawfully, or during or after the expiration of the term of his employment."

36. Accord Groucho Marx Prods., Inc. v. Day \& Night Co., 523 F. Supp. 485 (S.D.N.Y. 1981).

37. See Price v. Hal Roach Studios, Inc., 400 F. Supp. 836 (S.D.N.Y, 1975).

38. $25 \mathrm{Cal}$. 3d at 825,603 P.2d at 432, $160 \mathrm{Cal}$. Rptr. at 330 (Mosk, J., concurring).

39. Interestingly, this distinction mirrors that between authorship and performance rights in copyright law, for copyright does not recognize rights in performance.

Performance rights for theatrical performance have never been seriously considered. In Supreme Records v. Decca Records, 90 F. Supp. 904 (S.D. Cal. 1950), the court posited carrying asserted performance rights to their extreme where "Sir Laurence Olivier could prohibit anyone else from adopting some innovations which he brought to the performance of Hamlct." Id. at 909.

On the other hand, Congress has considered granting performance rights in sound recordings, allowing performers and copyright owners to share the proceeds garnered by a performer's sound and style. See Performance Rights in Sound Recordings: Hearings on H.R. 6063 Before the Subcomm. on Courts, Civil Liberties, and the Administration of Justice of the House Conm. on the Judiciary, 95th Cong., 2d Sess. (1978). See also Note, Performers' Rights and Copyright: The Protection of Sound Recordings from Modern Pirates, 59 CALIF. L. REV. 548 (1971). Nonetheless, courts have rejected the contention that the performer owns a proprietary right in that sound and style in relation to the performance of a copyrighted work. See, e.g., Simatra v. Goodyear Tire \& Rubber Co., 435 F.2d 711 (9th Cir.) (Nancy Sinatra held to have no rights to her rendition of "These Boots Are Made For Walkin' "), cert. denied, 402 U.S. 906 (1970); Miller v. Universal Pictures Co., 11 A.D.2d 47, 201 N.Y.S.2d 632 (1960) (no proprietary rights attached to the "Glenn Miller sound"), affd, 10 N.Y.2d 972, 180 N.E.2d 248, 224 N.Y.S.2d 662 (1961). 


\section{The Dissenting Opinion: The Copyright Model}

Chief Justice Bird, in a dissenting opinion joined by Justices Tobriner and Newman, concluded that the right to exploit one's name and likeness is descendible. The dissent postulated a copyright approach, looking to the federal copyright scheme for guidance in the publicity context. ${ }^{40}$ The Chief Justice thus advocated recognition of the right of publicity as a descendible right but one that ultiniately falls into the public domain after a fixed period. The Chief Justice suggested adoption of copyright's durational limit-life plus fifty years-as the appropriate period of protection. ${ }^{41}$

\section{a. The Traditional Copyright Model}

The model proffered by the Lugosi dissent is a traditional copyright model. Copyright law seeks to secure a fair reward for creative efforts so as to achieve two companion goals. ${ }^{42}$ The foremost is encouraging artistic endeavor. By offering creators an econounic benefit, copyright encourages people to engage in the arts. Considerable foregone opportunities inight otherwise deter development of talent and pursuit of inspiration. The stimulation of artistic effort in turn yields inore novels, paimtings, sculptures, and films for the public to enjoy.

The second goal, which tends to be overlooked as a policy justification for copyright, is to ensure that the return to the creator is a fair one. This goal is achieved by allowing the creator to enter the marketplace with an exclusive property-like interest in the product of his labors. A buyer must pay the fair market value for the rights to or a copy of the work. The traditional copyright inodel thus accounts for these two interests, with the policy of encouraging participation in the arts being the heightened concern. Chief Justice Bird acknowledged both artistic incentive and entitlement to the fruits of one's labors as coinpelling policy justifications for recognizing a right of publicity. ${ }^{43}$

Limitations imposed by the traditional copyright model allow it to meet its twin goals without overwhelming countervailing societal interests. Copyright law has both a subject unatter and a temporal limitation. These limitations allow copyright to coexist with the first

40. 25 Cal. 3d at 847, 602 P.2d at 446-47, 160 Cal. Rptr. at 344-45 (Bird, C.J., dissenting).

41. Id. Copyright protection for the author's life, and a fifty year period thereafter, is established by 17 U.S.C. § 302(a) (Supp. III 1979).

42. In Twentieth Century Music Corp. v. Aiken, 422 U.S. 151 (1975), Justice Stewart wrote "[c]reative work is to be encouraged and rewarded. . . . The immediate effect of our copyright law is to secure a fair return for an 'author's' creative labor. But the ultimate aim is, by this incentive, to stimulate artistic creativity for the general public good." Id. at 156 . In this manner, copyright law promotes "the Progress of Science and the useful Arts" as authorized by the Constitution. See U.S. CoNST. art. I, § 8, cl. 8 .

43. 25 Cal. 3d at $839-41,602$ P.2d at $441-42,160$ Cal. Rptr. at $339-40$ (Bird, C.J., dissenting). 
amendment and the policy favoring the unencumbered exchange of cultural infornation. The subject matter limitation is that while the unique expression of ideas is copyrightable, the ideas themselves are not protectable. ${ }^{44}$ By limiting the scope of the protections to the expression of a work, the copyright law does not abridge the dialogue of ideas generated by such works. ${ }^{45}$

The temporal limitation on copyright protection also makes copyright palatable to competimg imterests. ${ }^{46}$ Under the current act, copyright protection extends for a period of fifty years beyond the author's life. ${ }^{47}$ Congress believed that a fifty year post mortem right must be established to meet copyright's mcentive and reward interests. Thereafter, the interests in reward and encouragcment are presumed to wane and the work then falls into the public domam. Thus, a fifty year limit should be imposed when applying a copyright nodel to right of publicity cases. $^{48}$

\section{b. Applying the Traditional Copyright Model to Rights in Performance Cases}

The right of publicity has been invoked to protect two distinct interests: rights in performance itself and rights to the publicity figure's name and image. Granting damages for the broadcast of a human cannonball's stunt is an example of the former; enjoining the distribution of Elvis Presley posters illustrates the latter. This Section argues that the traditional copyright model, while readily applied in rights in perforinance cases, provides an imperfect and contrived framework by which to analyze cases imvolving the coinunercial rights to a performer's image.

The only right of publicity case to reach the United States Supreme Court concerned the protection of an artist's performance. Zacchini v. Scripps-Howard Broadcasting Co ${ }^{49}$ involved the fifteen second broadcast of Hugo Zacclimi's entire liuman cannonball act during a news telecast. The Court held that Zacclimi had a right of publicity in the stunt that did not infringe the first annendment. To loold otherwise, according to the Court, would threaten the circus artist's livelihood by ultimately decreasing the number of carmival patrons, whose

44. 1 M. NIMMER, NiMMER ON COPYRIGHT § 2.03[D] (1981).

45. Nimmer, Does Copyright Abridge the First Amendment Guarantees of Free Speech and Press?, 17 U.C.L.A. L. Rev. 1180, 1189-93 (1970).

46. Id. at 1193-94. Professor Nimmer suggests such a limitation for the then yet to be enacted period of protection.

47. 17 U.S.C. 8302 (a) (Supp. III 1979).

48. See infra notes 111-13 and accompanying text. See also Comment, Transfer of the Right of Publicity, supra note 2, at 1126-28.

49. 433 U.S. 562 (1976). 
curiosity would be satisfied by the broadcast. ${ }^{50}$ In reaching this decision, the Court specifically analogized from the law of copyright, stating that "the State's interest [in recognizing a right of publicity] is closely analogous to the goals of patent and copyright law, focusing on the right of the individual to reap the reward of his endeavors . . ."

The Court noted two policies supporting this right-the promotion of artistic effort and the prevention of unjust enrichment. As to the former, the Court noted that "the protection provides an economic incentive for [Zacchini] to make the investment required to produce a performance of interest to the public." 52 This protection, of course, is the basis for the copyright scheme. Preventimg unjust enrichment is also fostered because the author alone is entitled to the fruits of his labor througl a scheme which prevents unauthorized appropriation of the work. In the performance context, the Court held that "[n]o social purpose is served by having the defendant get free some aspect of the plaimtiff that would have inarket value and for which he would normally pay." 53

The Court thus applied a copyright model to protect rights in performance and thereby encourage participation in the performing arts. The Court could not directly rely on copyright because that statute does not recognize performance rights. ${ }^{54}$ There is thus a lingering question as to the propriety of the Court's grant of a possessory right in an area of the arts that Congress perceived as unworthy of a statutory scheme of reward and incentive.

Indeed, there is good reason for Congress' reluctance to protect the performing arts. Performers are customarily coinpensated for their creative labors by contracts with theatrical, film and music producers or with professional sports franchises. Through these contracts the parties can account for the opportunity costs associated witl training and rehearsal. Thus, there is a diminished interest in granting exclusive proprietary rights to the performance.

While the performer's incentive interests may be diminished, both it and the fairness interest are nonetheless not de minimis. Appropriation, for example, through videotaping a performance and broadcasting it during the course of an engagement, is likely to reduce gate revenues for the producer ${ }^{55}$ and ultimately reduce the compensation

50. Id. at $575-76$.

51. Id. at 573 .

52. Id. at 576 .

53. Id. (quoting Kalven, Privacy in Tort Law-Were Warren and Brandeis Wrong?, 31 LAw \& Contemp. Probs. 326, 331 (1966)).

54. See supra note 39 and accompanying text. Copyright promotes only those arts which can be rendered in a tangible medium of expression. 17 U.S.C. $\$ 102$ (a) (Supp. III 1979).

55. See 433 U.S. at 575-76. 
that the performer can exact. While the performer will still receive some compensation, recognizing a right of publicity would guarantee the performer fair compensation undiminished by unjust appropriation. ${ }^{56}$ Thus, through a right of publicity, a state can promote the performing arts im a manner comparable to the federal protection of the arts.

Zacchini, which dealt witl rights in performance, is a rare case. Most right of publicity actions involve questions of exclusive control over the performer's image, not over his or her act. In assessing the traditional copyright model, the distinction between the interest in the primary activity and the imterest in the image, which is a byproduct of that activity, must be kept in mind. While encouraging creative arts is a relevant concern in the rights in performance context, it becomes a largely gratuitous policy in publicity cases involving the marketing of name and likeness. ${ }^{57}$ It is true that one's name and likeness may prove to be a commercially valuable asset, and to this extent an exclusive marketimg right for one's image has an encouragement value..$^{58}$ Nevertheless, the prospect of full and fair compensation for performance and the unquantifiable value of fame ${ }^{59}$ proved to be sufficient incentive for performers long before the pop meinorabilia trade becalne so lucrative a busmess. Thus, the overall incentive value of a right to one's image is pragmatically diminished by preexistimg incentives and legally diminished by countervailing public interests that ought not bow to a gratuitous encourageinent policy.

Such was the rationale of the Sixth Circuit in Memphis Development Foundation v. Factors, Etc., Inc. ${ }^{60}$ Memphis Development souglit to determine whether the right effectively to market a statuette of the deceased Elvis Presley belonged to Presley's estate, its assignees and their hicensees, or to the public domain. The court implicitly analyzed the question with the traditional copyright approach.

It considered the personal interest in reward and the societal interest in encouraging the performing arts and balanced these interests agaimst the countervailing interests in free enterprise and, secondarily, free speech. ${ }^{61}$ Whereas the copyright model, if strictly followed, leads

56. Id. at 575 .

57. Hoffman, Limitations on the Right of Publicity, 28 Bull. CoPYRIaHT Soc'Y 111, 120 (1980).

58. For example, in his rookie season, Los Angeles Dodger pitcher Fernando Valenzuela proved to be a phenomenon both on the mound and in the marketplace. His first of many pop memorabilia contracts, a poster arrangement for $\$ 50,000$, exceeded his 1981 salary of $\$ 42,500$. $\mathrm{M}$. LITTWIN, iFERNANDO! 8, 13 (1981).

59. See Memphis Dev. Found. v. Factors, Etc., Inc., 616 F.2d 956, 958-59 (6th Cir.), cert. denied, 449 U.S. 953 (1980).

60. Id. at 956 .

61. Id. at $958-59$. 
to the conclusion that the right of publicity is descendible ${ }^{62}$ the $\mathrm{Mem}$ phis Development court reached the opposite conclusion. The court believed that the incentive interest was minimal because would-be performers sought the elusive status of fame and were at best only narginally propelled by the post mortem right to market their name and likeness. The interests im free marketplaces for pop merchandise and ideas should therefore be paramount. ${ }^{63}$ The Sixth Circuit thus determined that "whatever minimal benefit to society inay result from the added motivation and extra creativity supposedly encouraged by allowing a person to pass on his fame for the commercial use of his heirs or assigns," it does not outweigh the unencumbered "commercial, aesthetic, and political use of the name, inemory, and image of the famous." 64

This assessment of the validity of the encouragement rationale of the traditional copyright model casts doubt on the applicability of the model articulated in the Lugosi dissent. Nonetheless, copyright law presents an alternative model, a proposed byproduct model, which protects works notwithstanding the diminished incentive interest. The policy compelling protection under this model is the heightened interest in cominercial fairness which guards against unjust enrichment. Section II considers the proposed byproduct model and argues that it should be applied to publicity cases involving appropriation of a publicity figure's name or likeness.

\section{II \\ THE BYPRODUCT COPYRIGHT MODEL: Protecting GoODWILL}

The traditional copyright model represents the legislative balancing of the competing social interests in encouragement and reward agaimst the interests in free speech and free enterprise. Courts often apply this balancing in explaming why a work is copyrightable. Courts tend to use another approach, however, when explaining what is copyrightable. In determining what is copyrightable, courts often skirt the questions of pohicy justifications and use an approach that asks whether the subject matter at issue amounts to origmal expression eligible for copyright protection. Such an approach is conclusory, however. Even if the subject matter amounts to original expression, rather than an idea, it does not necessarily follow that this expression should be protected expression in light of copyright's aims.

The protected expression-or "what" approach-demands scru-

62. See infra notes $97-113$ and accompanying text.

63. 616 F.2d at 959-60.

64. Id. at 960 . 
timy because it is often used when the traditional "why" model is inapplicable. That is, under the protected expression approach courts will protect the expression of ideas regardless of the actual imcentive value underlying protection. This Comment argues that the protected expression approach is in fact supported by another compelling social policy: protecting the "popularity value"6s or goodwill generated by a work from unjust enrichment of the appropriator. This alternative model imvolves a heightened interest im the fairness associated witl copyright's fair reward tenet.

\section{A. Analogizing to Cases Involving Protection of Characters}

This approach is best illustrated in cases involving the protection of characters as component parts of a copyrighted work. Section three ${ }^{66}$ of the previous copyright law protected a work's component parts. ${ }^{67}$ Where the characters are the subject matter of the work, however, the mcentive value of such protection is dubious. Because copyright protects the entire work, the author is encouraged to produce it because the final product is protected. The ultimate goal of copyright-the creation of works of art-is attained by this protection. Separate protection for the character in a work is at most an incidental incentive for producing the ultimate creative product.

We must thus examine the rationales that support the copyrightability of cliaracters. Two theories have emerged from character cases: the "story being told" theory and the protected expression theory. The story being told theory is in essence a rearticulation of copyright's traditional encouragement and reward model. It protects characters in those rare instances when the literary crafting of a cliaracter is the work. This theory was developed in Warner Brothers Pictures v. Columbia Broadcasting System, ${ }^{68}$ where the Ninth Circuit considered the rights imuring to Daschiel Hammett's literary cliaracter, Sam Spade. The court concluded that a complete assignment of riglits to a copyrighted work did not imclude characters which were "vehicles" of the work. ${ }^{69}$ The court, im dicta, suggcsted that the cliaracter might be copyrighted when the claracter "really constitutes the story being

65. See Umbreit, A Consideration of Copyright, 87 U. PA. L. Rev. 932, 934-41 (1939).

66. Section 3 provided in part: "The copyright provided by this title shall protect all the copyrightable congruent parts of the work copyrighted, and all matter therein in which copyright is already subsisting, but without extending the duration or scope of such copyright." 17 U.S.C. $\S 3$ (1976) (repealed 1976).

67. E.g., Walt Disney Prods. v. Air Pirates, 581 F.2d 751 (9th Cir. 1978) (finding that Mickey Mouse and other Disney characters are copyrightable).

68. 216 F.2d 945 (9th Cir.), cert. denied, 348 U.S. 971 (1954).

69. Id. at 950. 
told."70 The encouragement prong of the copyright model thus applies because there is an incentive interest if the character and work are inseparable. The creation of a character is protected and encouraged because that character is the work, the creation of which is the goal of the statutory scheme.

The second theory advanced for the copyrightability of characters inay be identified as the protected expression theory. This theory arises in the context of graphic characters. It steins from the earliest character cases involving cartoon figures whose images were produced and marketed in different mediums. ${ }^{71}$ The theory has been subsequently refined in recent cases involving cartoon characters, ${ }^{72}$ animated three-dimensional figures, ${ }^{73}$ and inovie robots. ${ }^{74}$ In Walt Disney Productions v. Air Pirates, ${ }^{75}$ the Ninth Circuit ruled that the venerable Mickey Mouse and other Disney characters were copyrightable, and that unauthorized use in a series of underground comic strips constituted infringement. The court determined that cartoon characters, because of their distinct configurations, are original expression and thus warrant protection. The court stated that "while many literary characters may embody httle more than an unprotected idea, a comic book character, which has physical as well as conceptual quahties, is inore likely to contain some umque elements of expression."76 The court thus used the protected expression test: once the subject was seen as a graphic expression, it followed that the subject was protected expression. In essence, the court used a "what" test instead of a "why" test, basing its decision on what is copyrightable without considering that copyright's primary policy rationale-encouragement-is substantially diminished when the copyrighted subject is a part of a larger copyrightable work.

The protected expression test was more fully articulated in Sid \& Marty Krofft Television Productions v. McDonald's Corp. ${ }^{77}$ That case involved the three-dimensional fantasy characters of the plaintiff's "H.R. Pufnstuf" television show. Defendants used substantially similar figures in their television advertising campaign. The court determined that the characters were copyrightable and that McDonalds'

70. Id.

71. King Features Syndicate v. Fleischer, 299 F. 533 (2d Cir. 1924); Hill v. Whalen \& Martell, Inc., 220 F. 359 (S.D.N.Y. 1914).

72. E.g., Walt Disney Prods. v. Air Pirates, 581 F.2d 751 (9th Cir. 1978). See also Walt Disney Prods. v. Air Pirates, 345 F. Supp. 108 (N.D. Cal. 1972), affd, 581 F.2d 751 (9th Cir. 1978).

73. Sid \& Marty Krofft Television Prods., Inc. v. McDonald's Corp., 562 F.2d 1157 (9th Cir. 1977) (infringement of the H.R. Pufnstuf characters in a McDonaldland TV commercial).

74. Ideal Toy Corp. v. Kenner Prods., Etc., 443 F. Supp. 291 (S.D.N.Y. 1977) (alleged infringement of the "Star Wars" droids and helmeted villain).

75. 581 F.2d 751 (9th Cir. 1978).

76. Id. at 755 (citations omitted).

77. 562 F.2d 1157 (9th Cir. 1977). 
unauthorized use of substantially similar figures constituted infringeinent. The critical question in an infringement action, according to the court, is whether the subject matter copied is the expression of an idea or the idea itself. ${ }^{78}$

Despite the apparently conclusory nature of the "what" test, it in fact includes a "why" element of its own: a heightened imterest in commercial fairness with only a secondary interest in encouraging artistic endeavor. This "why" coinponent thus reverses the emphasis of the companion policies that underlie the traditional copyright model. This alternative copyright model may be referred to as the byproduct model, because it explains why the byproducts of a larger copyrightable work are also protected. In 1939, Kenneth Umbreit examined copyright by products, particularly cartoon characters. He concluded that "what is being protected in these cartoon by-product cases is neither an idea, a character, nor a design but a popularity value, a sort of psychological property."79 Umbreit also asserted that in infringennent cases, the critical determination should be whether that whicli is appropriated is the idea or the popularity value generated by the work. ${ }^{80}$ The protected expression test inplicitly draws the same distmction. This popularity value represents an intangible appeal that can be turned to advantage in the marketplace. It is, im conventional terms, goodwill generated by the work.

This appropriation of goodwill notion is evident in the character cases. In King Features Syndicate v. Fleischer, ${ }^{81}$ one of the first cases to uphold the copyrightability of cartoon characters, the court held that a doll patterned after "Spark Plug" the horse infringed the copyright of that comic strip character. The court concluded that "the artist's concept of liumor was embodied in the copyrightable form," 82 a conclusion, in the lexicon of later cases, that the figure anounted to unique and protectible expression. Further, the court held that the character "cannot be copied by manufacturing a toy or doll as the appellees did, without taking the copyrightable form of that concept, and without at the saine time taking the commercial value-the fruits of the cartoonist's genius which consisted in his capacity to entertain and amuse." 83 While the court gave lip service to the mcentive element of

78. Id. at 1163. The court proposed a two tiered test. The first question is whether there is similarity of ideas, and the detẹrminative second question is whether the allegedly infringing product is substantially similar to the graphic appearance of the characters. Id. at 1164 .

79. Umbreit, supra note 65, at 939.

80. Id. at 952-53.

81. 299 F. 533 (2d Cir. 1924).

82. Id. at 538.

83. Id. 
the copyright law, ${ }^{84}$ it is quite clear that the court was primarily concerned with the effect of the law on the defendant, that is, preventing the defendant from "appropriating the genius of the artist."85 The policy rationale for protecting component parts in this instance is the guarding of an imtangible commercial value from unjustly enriching the purloiner.

The Krofft case is also rooted in this policy. At issue in Krofft was infringement of all of the components of the Pufnstuf show, not the characters alone. In such an instance the encouragenient rationale seems to support upholding the copyright. ${ }^{86}$ The opinion, however, turned to the prevention of "unlawful appropriation" as the conpelling reason for holding that unique expression is protected expression. The court held that "[t]o constitute an infringement, the copying nuust reach the point of 'unlawful appropriation,' or the copying of the protected expression itself."87 Again, the court focused on the defendant's behavior, noting that "[i]t is not surprising . . . that McDonald's hoped to duphicate this peculiar appeal to children in its commercials." peculiar appeal is, in other words, the goodwill generated by the Pufnstuf creators. Thus in Krofft, as in King Features, the compelling pohcy rationale is preventing unjust enrichinent of the defendant who uses the plaintiff's unique expression or a substantially similar imitation. ${ }^{89}$ The next Section argues that this unjust enrichinent rationale is also appropriate in image marketing cases.

84. Id. at 536 .

85. Id. at 535 .

86. See stpra notes $68-70$ and accompanying text.

87. 562 F.2d at 1165 .

88. Id. at 1166 (footnote omitted).

89. Other rationales can be advanced to justify the conclusion that unique expression is protected expression. The first is a return to plot theory, that is, that the work is nothing apart from its characters. Such a rationale was the substance of the district court's opinion in the Air Pirates case, where Judge Wollenberg noted that the principal appeal of Disney's works 'Ties with the character and nothing else." 345 F. Supp. at 113. Earlier courts, however, had been careful to find infringements only where both the character's appearance and his or lier actious were replicated in the defendant's work. E.g., National Comics Publications, Inc. v. Fawcett Publications, Inc., 191 F.2d 594, 600 (2d Cir. 1951); Detective Comics, Inc. v. Bruns Publications, Inc., 111 F.2d 432, 433-34 (2d Cir. 1940).

Another explanation of why unique expression should be treated as protected expression is simply that a distinct graphic or sculptural rendering like a cartoon figure is the type of work that copyright law norinally protects-that is, it is a work of original authorship that on its own falls within the subject matter of that which can be copyrighted. See 17 U.S.C. \& 102 (Supp. III 1979) (specifying hiterary works, musical works, dramatic works, pantomimes and clioreographic works, pictorial, graphic, and sculptural works, motion pictures and audio-visual works, and sound recordings as genres of authorship within the subject matter of copyright). This seemed to be the underying rationale of the Nimth Circuit's Air Pirates opimion. 581 F.2d at 755. 


\section{B. Application of the Byproduct Copyright Model in Image Marketing Cases}

Umbreit stated that there was no reason to limit the legal recognition of popularity value to subjects eligible for copyright. ${ }^{90}$ Indeed, popularity value generated by a celebrity should be protected by a right of publicity because the policies supporting the byproduct copyright cases-protecting goodwill and preventimg unjust enrichment-are identical to those implicated in the right of publicity cases. In image marketing cases, the extra value of a protectable, descendible, and marketable image is a marginal imcentive to the pursuit of a career in the performing arts. The perforner is compensated during his or her lifetime, and those very performers who create a marketable image are those whose services are most likely im demand. They are tlus less in need of the added incentive of a post mortem publicity right. ${ }^{91}$ The question then becomes one of commercial fairness. Should entrepreneurs be entitled to capitalize upon the goodwill of a public figure or celebrity, or should tliey be required to pay the commercial value that the figure's visage brings to the product? ${ }^{22}$ Under the byproduct copyright model, unique, distinct images ${ }^{93}$ generate goodwill which should be allocated to the creator and which should be within the marketing

90. Umbreit, supra note 65 , at $940-41$.

91. Hoffman, supra note 57 , at 119-20.

92. Several courts have suggested that this is the proper framing of the issue. See Factors Etc., Inc. v. Pro Arts, Inc., 579 F.2d 215, 221 (2d Cir. 1978), cert. denied, 444 U.S. 908 (1979); Lerman v. Chuckleberry Publications, 521 F. Supp. 228, 232 (S.D.N.Y. 1981); Ali v. Playgirl, Inc., 447 F. Supp. 723, 728-29 (S.D.N.Y. 1978) ("This common law publicity right is analogous to a comnercial entity's right to profit from the 'goodwill' it has built up in its name . . . ."); Grant $v$. Esquire, Inc., 367 F. Supp. 876, 879 (S.D.N.Y. 1973) ("The 'right of publicity' is somewhat akin to the exclusive right of a commercial enterprise to the benefits to be derived from the goodwill and secondary meaning that it has inanaged to build up in its name.").

93. One author has argued that the rights to the likeness of a publicity figure are subject to federal preemption under $\$ 301$ of the Copyright Act. To the extent that the right of publicity protects unique graplrie expression, it is vulnerable to preemption by the Copyright Act which protects works of authorship fixed in a tangible medium of expression. Shipley, Publicity Never Dies; It Just Fades Away: The Right of Publicity and Federal Preentption, 66 CORNell L. Rev. 673 (1981).

This argunient has been rejected in Factors, Etc., Inc. v. Pro Arts, Inc., 496 F. Supp. 1090, 1096-100 (S.D.N.Y. 1981) and in the Lugosi dissent, $25 \mathrm{Cal}$. 3d at 849, $603 \mathrm{P.2d}$ at 448 , $160 \mathrm{Cal}$. Rptr. at 346 (Bird, C.J., dissenting). In Factors, Judge Teuney sifted through the legislative history of the Copyright Act and concluded that Congress had no intent to preempt a state cause of action for a right of publicity, for this right involves "legal and equitable rights that are not equivalent to any of the exclusive rights within the general scope of copyright as specified by section 106." 496 F. Supp. at 1097. Moreover, the right to a "persona" and the right to a work of authorslip are qualitatively different. $I d$. at 1100 . Indeed, it is difficult to conceive of one's visage as the work of that person. It becomes valuable as a result of the person's creative endeavors, but it is not the product of those endeavors. Preemption inust be based on the nature of the subject and the legal rights designed to protect it, as opposed to the inedium in which it has been narketed. 
control of the creator or his assignee. For the person who has created a commercially valuable image as a byproduct of his or her efforts in the performing arts, that image should also be regarded as the fruit of that performer's labor and should be protected against unauthorized use.

The virtue of the byproduct copyright model is that it accounts for the countervailing societal interests in free speech and free enterprise while advancing the personal and societal aims of the right of publicity. The model protects unique expression, but does not protect the ideas expressed. In the right of publicity context, protection should be granted only to the figure's features and not what those features represent. Thus, in the Lugosi scenario, the image of Bela Lugosi should be protectable and the use of an anonyinous Count Dracula figure should not. Moreover, image marketing cases involve commercial speech which is not entitled to coinplete first amendment protection. ${ }^{94}$ Thus, the byproduct copyright model suggests that the interests in protecting one's distinct, commercially valuable visage outweigh the interest in free expression.

The interest in free enterprise, because of its speculativeness, should also bow to the right of publicity. It is by no means certain that allowing one's image to fall into the public domain will increase competition in pop memorabilia markets, because a question arises as to the identification of the relevant market. ${ }^{95}$ Is the relevant market that for merchandise bearing a given celebrity's likeness, such as Elvis Presley memorabilia, or is it pop hero merchandise in general? Perhaps the

94. The United States Suprene Court confirmed the evolving notion that commercial speech is protected by the first amendment in Virginia State Bd. of Pharmacy v. Virginia Citizens Consumer Council, 425 U.S. 748, 758-61, 770 (1976). The core of this principle is the notion that advertising is a vehicle for the flow of commercial infornation like price, quality, and location of a good or service. See id. at 763-65, 769-70. In the publicity context, however, a public figure's image or name, when associated with the product, does not contain commercial inforination. In the endorsement situation, it contains inforination along the lines of a referral by someone thought to garner public respect. This infornation has a psychological impact, rather than an econoumic information impact, and is one of the sources of deception in advertising that accounted for the longtime reluctance to recognize constitutional protection for commercial speecli. See Friedman v. Rogers, 440 U.S. 1, 16 (1979).

Commentators Felcher and Rubin have offered an analytical framework for approaching right of publicity cases which accounts for the different first amendment interests that may be implicated. Their inodel is elegantly simple: if the appropriation of a pop figure's name or likeness serves an infornational or entertainment function, it will be immune fron hability because of presumptively overriding first amendment interests. If, on the other hand, the name or likeness is used in the nierchandising context, it is without first amendment protection. See Felcher \& Rubin, Privacy, Publicity, and the Portrayal of Real People by Media, 88 YALE L.J. 1577, 1597-99 (1979). Thus while commercial speech enjoys constitutional protection, the first amendment should not shield the entrepreneur from hability for the appropriation of a celebrity's name or likeness where the entrepreneur's nse is clearly in a mercliandising context.

95. For a general discussion of the problems involved in determining the relevant unarket, see L. Sullivan, HaNDBOOK OF the Laws of ANTITRUSt 41-74 (1977). 
best answer is that the relevant market is subject to change. Under most circumstances, the market will be the whole pop figure T-shirt, poster or model market. Thus, the consumer will enjoy the benefits of competition between Elvis Presley and Bruce Springsteen posters regardless of whether a right of publicity is deemed descendible or freely exploitable. The market is likely to narrow, however, to that of a given figure's memorabilia when that person is involved in a highly publicized event such as a concert tour or a tragic death. In this market, an exclusive right of publicity may reduce competition. However, it is precisely then that the policies supporting the protection of a publicity figure's goodwill are most compelling and thus support the judicial sanction of monopoly power. ${ }^{96}$

Thus, application of the byproduct copyright model, with its heightened interest in protecting agamst unjust enrichment, provides an adequate basis for recognition of popularity value in image inarketing cases. The next Section applies this model to the pragmatic issues involved in these cases.

\section{III}

\section{Applying the Byproduct Coypright Model to IsSues in IMage Marketing Cases}

Right of publicity cases concerning the rights to one's naine and likeness involve several recurrent issues that this Section analyzes with the byproduct copyright model. Specifically this Section examines the descendibility of the right of publicity, the requirement of lifetime exploitation, and the rights inuring to an actor in a dramatic portrayal.

\section{A. The Descendibility of the Right of Publicity}

The majority of courts that have faced the issue have held that the right of publicity is descendible. ${ }^{97}$ Two courts have reached the opposite conclusion: the Lugosi court, which characterized the right as one of privacy, and the Memphis Development court, which balanced the same interests involved in the traditional copyright model. ${ }^{98}$ This Section considers the right of publicity cases and then demonstrates that

96. See infra notes 112-13 and accompanying text.

97. Factors Etc., Inc. v. Pro Arts, Inc., 579 F.2d 215, 221-22 (2d Cir. 1978), cert. denied, 449 U.S. 908 (1979); Groncho Marx Prods., Inc. v. Day \& Night Co., 523 F. Supp. 485, 487-88 (S.D.N.Y. 1981); Estate of Presley v. Russen, 513 F. Supp. 1339, 1350-51 (D.N.J. 1981); Factors Etc., Inc. v. Creative Card Co., 444 F. Supp. 279, 282, 28485 (S.D.N.Y. 1977); Price v. Hal Roach Studios, Inc., 400 F. Supp. 836, 844 (S.D.N.Y. 1975). Moreover, a Tennessee Chancery Court in Davidson County disagreed with the Sixth Circuit's assessment of the right of publicity in Memphis Development, holding that the right of publicity is inheritable. Commerce Umion Bank v. Coors of the Cumberland, Inc., 551 Pat. Trademark \& Copyright J. (BNA) A-3 (Oct. 2, 1981).

98. See supra notes $60-64$ and accompanying text. 
the byproduct copyright model compels the conclusion that the right of publicity is descendible.

Price v. Hal Roach Studios, Inc..$^{99}$ was the first case to recognize a descendible right of publicity. The widows and legatees of Stan Laurel and Oliver Hardy brought suit against the defendant studio to determine ownership of the exclusive merchandising rights of the screen comedians. The court noted that the rights to market one's naine and likeness had been characterized as property rights, ${ }^{100}$ and found descendibility to be the logical extension of the riglit's previously accepted assignability. The court thus held that "[t]here appears to be no logical reason to terminate this riglit upon the deatli of the person protected." 101

In Lugosi, Chief Justice Bird's dissent offered affirmative reasons favoring a descendible riglit of publicity. Given the parallel policy considerations of copyriglit, the Chief Justice concluded that "[s]ince the right of publicity recognizes an interest in tangible property similar in many respects to creations protected by copyright law . . . that body of law is mstructive" on the descendibility issue. ${ }^{102}$ The Chief Justice thus concluded that the right of publicity should be recognized for a period coextensive with copyright's scheme of life plus fifty years. ${ }^{103}$

This reliance on a traditional copyright model, lowever, is somewhat contrived. The dissent relies on both the incentive and unjust enrichment interests underlying traditional copyright law. ${ }^{104}$ As to the former, Chief Justice Bird noted that "grantimg protection after death provides an increased incentive for the imvestment of resources im one's profession, which may augment one's right of publicity." 105 While post mortem rights may provide some encouragement, the degree of that encouragement is probably de minimis. In the copyright realm, Congress determined that a post inortem right was a necessary incentive, and therefore granted a proprietary interest because tlie author is not otherwise compensated for his efforts. The performer, however, is usually fully compensated for services that ultimately create a inarketable likeness. Thus, it is dubious whether a post mortem riglt of publicity is a necessary incentive to performers, justifying the inhibition of commercial opportunity.

The Sixth Circuit in Memphis Development assessed the value of the right of publicity in light of coinpetimg social interests and deter-

\footnotetext{
99. 400 F. Supp. 836 (S.D.N.Y. 1975).

100. Id. at $844 \&$ n.12.

101. Id. at 844 .

102. 25 Cal. 3d at 847,603 P.2d at 446, 160 Cal. Rptr. at 344 (Bird, C.J., dissenting).

103. Id. at 847,603 P.2d at $446-47,160$ Cal. Rptr. at $344-45$.

104. Id. at $839-40,846,602$ P.2d at $441,445-46,160$ Cal. Rptr. at $339,343-44$.

105. Id. at 846,602 P.2d at 446,160 Cal. Rptr. at 344 .
} 
mined that, on balance, the interests in free enterprise and expression are greater than those fostered by a post mortem right of minimal encouragement value. In effect, the court applied the traditional copyright model, balancing the tension between encouragement and expression. ${ }^{106}$ Unlike the Lugosi dissent, which deferred to Congress' calculus in an analogous situation, the Sixth Circuit exercised independent judgment in rejecting the descendibility of the performer's right of publicity.

The Memphis Development court's assessment of the relative weights of the competing interests seems reasonable, but it conflicts with the result dictated by inechanical application of the traditional copyright model. This inconsistency may be resolved by noting that the traditional copyright model is simply the wrong inodel to apply in image marketing cases. Rather, in the merchandising context the byproduct copyright nodel should be applied because it gives primacy to the policy of preventing unjust enrichment. As noted above, the byproduct model effectively protects against the appropriation of the performer's commercially exploitable goodwill. ${ }^{107}$ Thus, the weakness of the Memphis Development court's approach is its failure to account for the social interest im commercial fairness attained by protecting goodwill created by the performer.

In a related case, Factors Etc., Inc. v. Pro Arts, Inc., ${ }^{108}$ the Second Circuit recognized a descendible right to the likeness of Elvis Presley. At issue was whether the right of publicity descended to the heirs of Presley, their assignees and licensees, or instead to the public domain. If the latter view prevailed, Pro Arts would not need to obtain a license to market its memorial poster. The court eschewed the encouragement rationale and instead considered the prospects of unjust enrichment. In the lexicon of this Comment, it applied the byproduct copyright model instead of the traditional copyright model. The court concluded that "[t]o hold that the right did not survive Presley's death, would be to grant competitors of [Presley's licensees] such as Pro Arts, a windfall in the form of profits from the use of Presley's name and likeness."109 This policy rationale bolstered the court's conclusion that the right of publicity survived the figure's death.

One difference between the Pro Arts and Memphis Development approaches is the pohicy rationale underlying copyright law to be con-

106. See 616 F.2d at 959-60.

107. See supra notes $90-96$ and accompanying text.

108. 579 F.2d 215 (2d Cir. 1978), cert. denied, 444 U.S. 908 (1979).

109. Id. at 221. Accord Lerman v. Chuckleberry Publications, 521 F. Supp. 228, 232 (S.D.N.Y. 1981); Ali v. Playgirl, Inc., 447 F. Supp. 723, $728-29$ (S.D.N.Y. 1978); Grant v. Esquire, Inc., 367 F. Supp. 876, 879 (S.D.N.Y. 1973). 
sidered. In the image inerchandising context, as in the copyright of character context, it is presumed that the encourageinent rationale has diminished value. Thus, the policy supporting protection in the copyright context, unjust enrichment, must also support the Pro Arts publicity case. Application of this copyright model, like application of the traditional model, leads to the conclusion that the right of publicity is descendible. Congress determined that the control of a work having post mortem value should inure to the author's heirs. ${ }^{110}$ Similarly, control over the performer's image should inure to the lieirs; to hold otherwise would allow inerchandisers to freely capitalize on the goodwill created by the performer.

Acknowledgment of a post mortem right of publicity, however, has been met with caution because of a reluctance to burden expression and enterprise with ghosts of the past. The byproduct copyright model addresses this concern by grafting a temporal limitation onto the right of publicity. Indeed, in the Lugosi dissent Chief Justice Bird suggested adoption of copyright's limitation period of life plus fifty years. ${ }^{111}$

This temporal limitation is not simply derived from Congress' copyright model. It additionally accounts for the shift in policy interests with the passage of time. For example, the time of the celebrity's death is precisely when protection is inost desirable because death itself may resurrect a dormant commercial value or goodwill in one's name and likeness. The surge of John Lennon and Elvis Presley memorabilia upon their deaths amply illustrates this point. ${ }^{112}$ Over time, however, public interest in a celebrity dwindles but the social interest in unhindered enterprise and expression remains. ${ }^{13}$ Moreover, should mterest in a celebrity revive after fifty years, that interest is most likely to be attributed to goodwill generated not by the performer but by entreprenurial efforts of film distributors or pop inerchandisers. Thus, after a period of time such as fifty years, the need, indeed the wisdom, of protecting agamst unjust enrichment becoines questionable.

110. See supra note 47 and accompanying text.

111. See supra notes $102-03$ and accompanying text.

Such an approach involves the necessary linedrawing to address the concerns of Judge Merritt in Memphis Development and Justice Mosk in Lugosi that the use of a publicity figure's name and likeness not be tied up in perpetuity. See Memphis Development, 616 F.2d at 959; Lugosi, 25 Cal. 3d at 825-26, 603 P.2d at 432, 160 Cal. Rptr. at 330 (Mosk, J., concurring).

112. For an account of this phenomenon, see N.Y. Times, Jan. 12, 1981, at D9, col. 3, where it is observed that:

Unlike the fans of Elvis Presley, who quickly snapped up everything from records to key chains to whiskey bottles in the inage of the rock star after his death in 1977, devotees of

Mr. Lennon and the Beatles appear to be less interested in inemorabilia than in charitable donations in the singer's name.

Nonetheless, the writer concedes that " $t$ t]he T-shirts, books, meınorial nnagazines, and buttons that appeared almost instantly after the singer was slain sold fairly well at first . . ." Id.

113. See Comment, Transfer of the Right of Publicity, supra note 2, at 1126-28. 


\section{B. The Prerequisite of Lifetime Exploitation}

Related to the descendibility issue is the question whether the publicity figure must exploit his or her name or likeness during life to retain a post mortem right of publicity. Several courts have suggested that lifetime exploitation is a prerequisite for recogmition of a post mortem right. ${ }^{114}$ The Pro Arts court, for instance, bolstered its holding on the descendibility issue by noting that Elvis Presley had exploited his name and likeness in his lifetime. ${ }^{15}$ The rationales behind weighing, if not requiring, lifetime exploitation have been thoughtfully articulated by Felcher and Rubin, ${ }^{116}$ but their analytical approach is inconsistent with the application of a copyright inodel. Application of the byproduct copyright model would lead to the conclusion that an image maker need not engage in lifetime exploitation in order to preserve the post mortem right.

Felcher and Rubin offer two justifications for the necessity of lifetime exploitation. First, they argue that the plaintiff must demonstrate that there has been actual economic injury in order to sustain an action for violation of the right of publicity. Lifetime exploitation is evidence that the image's commercial value is real rather than a matter of fanciful speculation. ${ }^{17}$ The second rationale is predicated on the application of the traditional copyright model, which presumes that the post mortem right of publicity encourages endeavor in the performing arts. Felcher and Rubin submit that a failure to exploit an image in one's lifetime indicates that the financial reward of exploitation of name and likeness lias no real mcentive value because the performer committed talent to the performing arts without exploiting the right. ${ }^{118}$ The ultimate social goal of encouraging that performer is thus mapplicable and to recognize an additional incentive-based right is therefore gratuitous. Thus, according to Felcher and Rubim, the right of publicity must fall to the public domain, so as not to burden expression and enterprise unnecessarily.

114. See, e.g., Groucho Marx Prods., Inc. v. Day \& Night Co., 523 F. Supp. 485, 492 (S.D.N.Y. 1981); Estate of Presley v. Russen, 513 F. Supp. 1339, 1355 (D.N.J. 1981).

115. 579 F.2d at 222. In a footnote, however, the court expressly denied holding that this is a requirement. Id. \& n.11 ("Because the right was exploited during Presley's life, we need not, and therefore do not, decide whether the right would survive the death of the celebrity if not exploited during the celebrity's life."). Moreover, it is doubtrul whether the establishment of such a prerequisite would defeat a publicity claim in the vast inajority of cases. Any performer who creates a marketable image is likely to have engaged in pronoting that image in his or her lifetime. See, e.g., Groucho Marx Prods., Inc. v. Day \& Night Co., 523 F. Supp. 485, $491-92$ (S.D.N.Y. 1981) ("Every appearance, contract and advertisenent involving the Marx Brothers signified recognition by the performers of the commercial value of unique characters they portrayed.").

116. Felcher \& Rubin, supra note 94, at 1613-15; Fclcher \& Rubin, supra note 2.

117. Felcher \& Rubin, supre note 94 , at 1613-15.

118. Id. at 1614; Felcher \& Rubin, supra note 2, at 1130-31. 
The byproduct copyright model and the mutually applicable policies supporting its apphication both counter the Felcher and Rubin rationales and compel the contrary conclusion. The publicity figure's interests, like the author's, are financial remuneration and control. Copyright law has long granted the author's autonomy to market the work as he sees fit, including the decision not to market the product at all. Prior to 1978 a work that was not published was nonetheless protected by common law copyright, ${ }^{119}$ and under the new copyright act that saine work is now statutorily protected when created. ${ }^{120}$ That protection, once conferred, is not relinquished if the work is never marketed. Thus, copyright law protects the author's marketing and publishing autonomy without compelling exploitation. In the right of publicity context, to determine injury on the basis of previous financial reinuneration alone is to ignore the injury sustained by intrusion on the performer's image-marketimg control. In the publicity context, as in the publication context, a performer who chooses not to exploit his image is $\mathrm{m}$ fact exercising control over this commercial right in the same manner as the performer who "cashes in." 121

Consider, for example, the performer who has not merchandised his or her naine or likeness because the timing is thought to be inopportune. Performers, before achieving any significant degree of popularity, would not want to license the right to their appearance because they could exact only a speculator's price. They may prefer to wait until their image is at its most marketable or most promising value. If a performer dies without exercising control and subsequently-perhaps precisely because of the interest generated by the performer's deaththe image becomes commercially valuable, and the performer should not be treated differently from those who actually market their images during life for either sound or foohsh busmess reasons. The asymmetrical treatment, defended by Felcher and Rubin, of this performer and those who inarket their images during life is not justified by the differences in marketing behavior. The two figures should be treated the same with respect to the recognition of post morten rights in publicity. The byproduct copyright model suggests that a descendible right of publicity should imure to both.

119. M. NiMmER, supra note $44, \S 4.01[B]$.

120. 17 U.S.C. \& 104 (Supp. III 1979).

121. See Grant v. Esquire, Inc., 367 F. Supp. 876 (S.D.N.Y. 1973), where the court compared the marketing conduct of a reticent Cary Grant with that of the commercially active Twiggy. The court considered:

whether the rights of plaintiff Grant-because of his renunciation of any desire to exploit the commercial value of his own name and fame--should be any different than those of Twiggy. We think not. If the owner of Blackacre decides for reasons of his own not to use his land but to keep it in reserve he is not precluded from prosecuting trespasses. Id. at 880 . 
The second rationale advanced by Felcher and Rubin is that use of this right of value during the figure's lifetime demonstrates that this opportunity is indeed an incentive for the perfornner to engage in his or her chosen career, and thus the limitations on speech, commercial and otherwise, are justified. ${ }^{122}$ This notion follows from the traditional copyright model, in which first amendment interests bow to the superseding societal interest of promoting the arts. Such a rationale applies in the performance cases, where there is indeed an interest in encouragement, ${ }^{123}$ but is less convincing in the merchandising genre where the encourageinent interest is minimal.

The societal interest that should instead be advanced is the protection against unjust enrichment. The relevant issue is the allocation of goodwill generated by a performer. Resolution of this issue should not be predicated on the figure's lifetime marketing decisions. Rather, the inquiry is whether the goodwill was generated by the figure or by the merchandiser. ${ }^{124}$ A workable solution is to follow the copyright approach and hold that goodwill used within fifty years of a publicity figure's death is presumptively credited to the figure. After fifty years if the image becomes merchandisable the goodwill is attributed to the entrepreneur's efforts to rekindle an interest in the figure. Therefore, the public interest im the accessibility of such cultural and commercial information properly takes precedence. ${ }^{125}$

122. Felcher \& Rubin, supra note 2, at 1130-31. This rationale supported a lifetime exploitation requirement in Hicks v. Casablanca Records \& Filmworks, 464 F. Supp. 426 (S.D.N.Y. 1978), where the court held "a party claiming the right [of publicity] must establish that the decedent acted in such a way as to evidence his or her recognition of the extrinsic commercial value of his or her name or likeness, and manifested that recognition in some manner . . . ." Id. at 429.

123. See supra notes $49-56$ and accompanying text.

124. When the Lugosi inajority added a lifetime marketing requirement, it relied on an unfair competition theory. The majority was concerned with whether the actor had created an imagemarketing business associated with the marketing of Bela Lugosi or Count Dracula products. 25 Cal. 3d at 818-24, 603 P.2d at 428-31, 160 Cal. Rptr. at 326-29. The test for a violation of sucl a commercial right is whether the product has generated a secondary meaning, that is, whether it has become associated in the mimds of the public with its producer. This test looks to the consamer and determines whether the infringing product, by identifying itself in a similar manner to the product which lias acquired secondary meaning, confuses the consumer as to its source. See 1 J. MCCARTHY, TRADEMARKS AND UNFAIR COMPETITION \& 15:2 (1973). Right of publicity cases, however, deal with images, not businesses, and with determining the allocation of goodwill rather than misrepresentation as to the source of the goodwill once the rights to it are settled. See Unbreit, supra note 65, at 940.

125. This approach may be administered in two ways. The first is to treat the 50 year period as a conclusive presumption, a rule of substantive law that stands regardless of the facts and cquities in any given case. Such an approach has two advantages: administrative convenience and commercial uniformity in the realm of pop image mercliandising. If the fixed 50 year period is adopted, courts may uphold the right of publicity without tracing the sources of the goodwill. To allow such tracing may lead to extensive hitigation over an issue that can never be satisfactorily resolved. Moreover, adopting the fixed time period as a conclusive presumption provides protection of publicity figures coextensive with copyright protection. The message to pop image mer- 


\section{A Right of Publicity for an Actor in the Portrayal of a Dramatic Character}

The previous discussion concerned the merchandising rights to a performer's image. The Lugosi case raised another question: whether the same rights mure to an actor when the image marketed is that of a dramatic stage or screen character. Justice Mosk's concurring opinion in Lugosi ${ }^{126}$ the swing vote in the case, found that an actor could not establish a protectable commercial right in the portrayal of a character permed by another. He believed that the commercial rights belong to the studio as the product created by an employee during the course of his employment pursuant to section 2860 of the California Labor Code. On the other hand, Justice Mosk was willing to recognize an actionable right of publicity for those performers who portray themselves. This category would imclude, for example, the Marx Brothers, Laurel and Hardy, and presumably athletes.

The distimction between performers portraying themselves and those portraying fictional characters is neither compelled by the statute nor supported by the policy rationales establishing a right of publicity. In the peculiar case of the actor portraymg a fictional character, the commercial rights to the character's likeness should be distributed equitably among the interested parties.

Section 2860 has been applied primarily to cases involving the protection of trade secrets and confidential busimess information. ${ }^{127}$ It is also applied in cases where an employee attempts to claim property rights im a product which he was employed to create. ${ }^{128}$ The Copyright Act of 1976 contains a similar provision: the rights to works made for

chandisers is clear: refrain from using any figure's image for a 50 year period whether that figure is an animated character, a movie robot, a ghoulish actor, or a celebrity.

The second approach is to treat the 50 year period of protection as a rebuttable presuinption, thereby allowing parties to present evidence as to the actual source of the goodwill that has made the image valuable. Thus, the entrepreneur would have the opportumity to present evidence that the goodwill associated with the figure was not traceable to that person's lifetime exploits. Conversely, the heirs could assert that protection should last for more than 50 years because the continumg marketability of the image is not the result of a rekindling of the image by enterprising members of the public. This approach accounts for cases whose facts run counter to the underlying presumptions that support allocating the goodwill of the performer for the 50 year period. Placing the burden on the parties seeking to overcoine the underlying presumptions makes the ultimate determination inore equitable without unduly burdening the factfinder.

126. 25 Cal. 3d at 824-28, 603 P.2d at 430-34, 160 Cal. Rptr. at 329-32 (Mosk, J., concurring).

127. See KGB, Inc. v. Giannoulas, 104 Cal. App. 3d 844, 855, 164 Cal. Rptr. 571, 582 (4th Dist. 1980).

128. See, e.g., Treu v. Garrett Corp., 264 Cal. App. 2d 432, 436-37, 70 Cal. Rptr. 284, 287 (2d Dist. 1968); Zahler v. Columbia Pictures Corp., I80 Cal. App. 2d 582, 589, 4 Cal. Rptr. 612, 617 (2d Dist. 1960). CAL. LAB. CODE $\$ 2860$ (West 1971) "has not been used to protect an actor's or artist's creations during einployment in the absence of a contract providing express protection." Giannoulas, $104 \mathrm{Cal}$. App. 3d at 855, 164 Cal. Rptr. at 582. 
hire belong to the employer. ${ }^{129}$

For the motion picture "Dracula," Bela Lugosi was compensated by Umiversal for his performance, that series of gestures and articulations which left a haunting impression on the audience. The creation of a unique and marketable image, however, was a separate byproduct for which Lugosi was not compensated. The trial court's interpretation of the 1930 Dracula employinent agreement supports this distinction. The agreeinent granted Universal the rights to the name and likeness of Lugosi im order to promote the film. The trial court accordingly found that the commercial rights to the name and likeness of Lugosi, apart from advertising for the motion picture, had not been contractually allocated. ${ }^{130}$ Lugosi was thus coinpensated for his performance and for the creation of an image to be used for advertising purposes alone, but was not coinpensated for the creation of a marketable name and likeness. This latter element is outside the scope of section 2860 .

It is therefore appropriate to consider the policy rationales behind recognizing or denying a right to exploit the likeness of a portrayed character. As established earlier, the primary policy is commercial fairness. In this context, fairness customarily demands treating like circumstances alike. As discussed earlier, purely fantastic and graphically distinct characters, like cartoons, puppets, and robots, are protectable under copyright law. Most courts, including a najority of the justices of the Califorma Supreme Court deciding Lugosi, believe that a right of publicity exists for individuals seeking to market their own image. There is thus a continuum, with copyright offering a post mortern right of the character image on one end and common law rights of publicity protecting the image of a celebrity on the other. The Count Dracula figure falls somewhere in between, for its physical manifestation is a synthesis of the distinct appearance of the actor and the artistry of the studio's substantial contributions in makeup, costuming, lighting, and direction.

There is no good reason why a jointly created image should be treated differently fron 1 an image that is either wholly a studio creation or one that is the result of a celebrity's features. Indeed, there is good reason to treat these images in similar fashion. Uniform rules should govern what ultimately amounts to the inerchandising rights to a media image. The opportunities available to nerchandisers should not depend on whether this distinct marketable image is an original studio or animator creation, a celebrity, or an actor in the portrayal of a dramatic role. This uniform approach determines the rights of merchandisers

129. 17 U.S.C. § 201(b) (Supp. III 1979). See I7 U.S.C. § I01 (Supp. III 1979) for a definition of a "work made for hire."

130. 172 U.S.P.Q. (BNA) 541, 543-44 (Cal. Super. Ct. 1972). 
and restricts their opportunities while preserving the societal goals of granting the creator of the image control over the fruits of his or her labor and secondarily adding incentive to participation in the performing arts.

Once the right to preservation of the image of a dramatic character as portrayed by an actor is recognized, an allocation question arises. The graphically unique character and the celebrity present easy cases. Their rights belong to the creator of the character or to the celebrity. The image of an actor in the portrayal of a dramatic character, however, represents a synthesis of significant efforts of both the actor and the production team. Both parties deserve rights to commercial exploitation.

Again, copyright law provides an analogue by which to partition rights. Copyright law grants inultiple interests to the authors of joint works, each of whom contributed to the final work that is protected by a single but jointly enforceable copyright. ${ }^{131}$ Critical to the recognition of a joint right in copyright is that the parties intend their work to be collaborative and in furtherance of a common design. ${ }^{132}$ This requirement is fulfilled in the actor-director-producer relationship.

In the right of publicity context, as in copyright, the pohicy interest of rewarding the fruits of labor is advanced by recognizing a joint right of publicity to an image like that of Count Dracula, which is the distinct result of the actor's unique features and the studio's unique and substantial enhancement of those features. Recently, a news bulletin in an entertainment journal reported that Universal Pictures, the Lugosi defendant, was in the process of initiating a lawsuit against commercial merchandisers for copyright infrimgement of the Frankenstein monster character. ${ }^{133}$ Under the proposed analysis Universal enjoys a joint right of publicity, not as a matter of copyright but coextensive with copyright, with the actor Boris Karloff, who portrayed the Frankenstein monster. ${ }^{134}$

This joint right would allow either party to market the iniage. ${ }^{135}$

131. 17 U.S.C. \& 201(a) (Supp. III 1979). A joint work is defined as a "work prepared by two or more authors with the intention that their contributions be merged into inseparable or interdependent parts of a unitary whole." Id. \& 101.

132. $1 \mathrm{M}$. NIMMER, supra note $44, \S 6.03$.

133. Daily Variety, Mar. 5, 1981, at 4, col. 5.

134. Universal's rights stem from the substantial enhancement of Karloff's features in creating the Frankenstein monster. Ironically, Karloff himself designed the makeup pursuant to a contract with the studio and was compensated for this work. This work product therefore belongs to the employer. See supra note 128 and accompanying text.

135. Such is the general rule in copyright law where one joint owner may exploit a work without the consent of the other. See $1 \mathrm{M}$. NIMMER, supra note 44, \& 6.10. Nimmer notes exceptions to this principle where the licensing of a work would cause its destruction and where the joint authors have agreed previously to ticense ouly in concert. Id. 
Indeed, both the actor and the studio have an imterest in marketing the image in as thoughtful a manner as possible. This policy of joint control thus avoids the problem of wasting the asset. ${ }^{136}$ Moreover, joint control will serve as a clieck on estatc administrators of a deceased actor who may want to withhold the name and likeness from commercial exploitation to honor the privacy of the deceased. Common law has refused to protect the privacy of the dead, ${ }^{137}$ and it follows that a joint right that favors merchantability over privacy interests is an acceptable, indeed preferable, limitation on the heirs' marketing autonony.

With a joimt right, both parties are entitled to an accounting and a division of the proceeds for the use of the figure's innage. The parties would have no injunctive rights agamst eacli otler, but would retain such remedies for unauthorized appropriation by others. The desirability of these remedies is demonstrated by Lugosi. An irony of that decision is that it not only denied such rights to the lieirs, but also denied them to Universal, which liad licensed the use of Dracula and other horror picture characters to nierchandisers. According to the $\mathrm{Lu}$ gosi decision, Universal had no greater rights in the Dracula image than any other meniber of the public. ${ }^{138}$ The Lugosi decision thus proved to be a Pyrrhic victory for Universal. The recognition of the joimt right proposed in this Comment, on the other hand, would have accommodated the interests of both Lugosi litigants and forced merchandisers to pay the commercial value attached to the image that the parties jointly created.

\section{CONCLUSION}

Right of publicity cases protect the creations of the performer, which may amount to rights to the performance itself or rights to the performer's commercially valuable image. Protection of a distinct physical image parallels, im nrany respects, protection of the unique graphic renderings of characters im a larger body of work. At issue is the protection of goodwill generated by such an image against appropriation by merchandisers selling a product whose value is imseparable from the value of the publicity figure's image. Given the similarities in policies, there is sound reason for applying the standards set by Congress in the Copyright Act. The application of these standards will further the personal and public interests to be balanced in right of

136. See supra note 13 and accompanying text.

137. See supra note 34 and accompanying text.

138. 25 Cal. 3d at $822-23,603$ P.2d at 430,160 Cal. Rptr. at 328. 
publicity cases, and moreover, will create uniform standards for the marketing of pop figure images.

Kevin S. Marks*

* A.B. 1979, Stanford University; third-year student, Boalt Hall School of Law, University of California, Berkeley. 